\title{
SICK LEAVE EXPERIENCE OF CIVIL SERVANTS IN THE GOVERNMENT OF NORTHERN IRELAND DURING 1958
}

BY

\author{
A. T. PARK \\ AND \\ C. W. KIDD
}

Ministry of Finance and Ministry of Health and Local Govermnent, Northern Ireland

In the absence of any completely satisfactory morbidity statistics comparable to the Registrar General's mortality records, covering the whole population, reports on the sickness experience of relatively small groups of people are available from time to time. Such groups are commonly select sections of the population for which figures have been specially compiled for one reason or another; the following are representative examples in this field.

Barr (1960) reported in some detail on the sickness absence of the nurses of a Regional Hospital Board. Spratling (1957) described that of the employees of London Transport Executive in a most comprehensive way. Chiesman (1957) reported "sick rates" for various grades of post office staff and his data has been used by many workers for the purpose of special studies into the incidence of ischaemic heart disease and the like in various grades of post office employment (Morris, 1957; Reid, 1957). The morbidity experience amongst the staff of local authorities has been reported by Moss (1959) and Warren (1960).

On a national scale data derived from the administration of the National Insurance Schemes are available for Great Britain and Northern Ireland on a sample basis. While there are limitation in this material, a broad picture of sickness occurring in a large section of population between the ages of 15 and 65 is available for study (Park and Kidd, 1958; Jones, 1959; Kidd and Park, 1959; 1960, a, b).

It is important that consideration should be given to morbidity studies from all possible sources in an endeavour to obtain information of value in piecing together the pattern of community sickness; in what follows reference is made to the sickness experience of a relatively small population (about 7,000), comprising the non-industrial staff of the Civil Service of the Government of Northern Ireland.
A survey of sick leave among civil servants in Northern Ireland was prepared from information received from Government Departments in respect of all spells of sick leave taken by their staffs during 1958. There were no serious epidemics during that year and, indeed, amongst insured persons in the Province, the average number absent from work during 1958 was the lowest since the inception of the National Insurance Schemes in 1948. A factual account of the results of this survey was given in a previous study, published elsewhere, by Kidd and Park (1960b). As established civil servants have to pass a medical examination before appointment, they are in a way selected lives and a different pattern of sickness from that of the rest of the insured working population in the Province would be expected. The survey revealed that civil servants did have on average more spells off work but that these spells were of shorter duration and in terms of days lost per head during the year amounted to about half that for the rest of the insured population in Northern Ireland. This experience may be unique to the civil service or, on the other hand, it may be typical of office staff generally. It is notable that, while the influence of occupation on mortality has been studied for many years, little is known of the influence of occupation on morbidity. Unfortunately no breakdown by occupation of the morbidity data from national insurance records in Northern Ireland is available.

Spratling (1957) suggested a way of comparing the recorded sickness absence of a particular occupational group with the amount of sickness absence that would have been recorded if the experience of the group under examination had been the same as that of the relevant London Transport group during the years 1949-52. The most appropriate of their groups for comparison with Northern Ireland civil servants were, for men, the clerical and technical 
staff, and for women, the clerical staff (unmarried women)-there are no married women in the Northern Ireland civil service.

The civil service data were available for only one year (1958) and, unlike the London Transport data, included spells lasting more than 6 months although the small numbers of such cases should not seriously affect the comparison. It was only possible to make the comparison for the number of days of sickness because of the method of compiling the figures for uncertificated leave (spells of less than 3 days' duration) in the civil service.

As can be seen from Table I, the number of days taken by male civil servants of all ages was 3 per cent. higher than expected from the London Transport data, but the differences between observation and expectation varied quite appreciably between age groups. This variation did not suggest any formal relationship with age. Amongst unmarried women, civil servants had 6 per cent. fewer days' absence than expected and at ages up to 25 this difference was appreciable.

\section{TABLE I}

COMPARISON OF ACTUAL CIVIL SERVICE EXPERIENCE DURING 1958 WITH EXPECTED EXPERIENCE ACCORDING TO TABLES FOR LONDON TRANSPORT CLERICAL AND AND TECHNICAL STAFF, 1949-52

\begin{tabular}{|c|c|c|c|c|c|c|}
\hline \multirow[b]{2}{*}{$\begin{array}{c}\text { Employ- } \\
\text { ment }\end{array}$} & \multirow[b]{2}{*}{ Sex } & \multirow[b]{2}{*}{$\begin{array}{l}\text { Age } \\
\text { Group } \\
\text { (yrs) }\end{array}$} & \multirow[b]{2}{*}{$\begin{array}{l}\text { No. } \\
\text { of } \\
\text { Staff } \\
\text { in } \\
\text { Post }\end{array}$} & \multicolumn{3}{|c|}{ Days of Sickness Absence } \\
\hline & & & & Actual & $\begin{array}{c}\text { Ex- } \\
\text { pected }\end{array}$ & $\begin{array}{l}\text { Actual as } \\
\text { Percentage } \\
\text { of } \\
\text { Expected }\end{array}$ \\
\hline \multirow[t]{2}{*}{$\begin{array}{l}\text { Clerical } \\
\text { and } \\
\text { Technical }\end{array}$} & \multirow[t]{2}{*}{ Males } & $\begin{array}{l}\text { Up to } 19 \\
20-24 \\
25-29 \\
30-34 \\
35-39 \\
40-44 \\
45-49 \\
50-54 \\
55-59\end{array}$ & $\begin{array}{r}88 \\
259 \\
280 \\
379 \\
742 \\
680 \\
488 \\
406 \\
387\end{array}$ & $\begin{array}{r}203 \\
1,366 \\
1,200 \\
2,783 \\
7,391 \\
5,360 \\
4,777 \\
5,172 \\
5,050\end{array}$ & $\begin{array}{r}299 \\
1,344 \\
1,552 \\
2,605 \\
6,444 \\
5,883 \\
4,514 \\
4,316 \\
5,508\end{array}$ & $\begin{array}{r}68 \\
102 \\
77 \\
107 \\
115 \\
91 \\
106 \\
120 \\
92\end{array}$ \\
\hline & & Total & 3,709 & 33,302 & 32,465 & 103 \\
\hline \multirow[t]{2}{*}{ Clerical } & \multirow[t]{2}{*}{$\begin{array}{l}\text { Single } \\
\text { Women }\end{array}$} & $\begin{array}{l}\text { Up to } 19 \\
20-24 \\
25-29 \\
30-34 \\
35-39 \\
40-44 \\
45-49 \\
50-54 \\
55-59\end{array}$ & $\begin{array}{l}533 \\
776 \\
437 \\
340 \\
370 \\
235 \\
202 \\
220 \\
157\end{array}$ & $\begin{array}{l}2,681 \\
7,476 \\
5,547 \\
4,391 \\
4,552 \\
2,831 \\
2,591 \\
3,074 \\
2,897\end{array}$ & $\begin{array}{l}5,421 \\
8,949 \\
5,233 \\
3,380 \\
3,633 \\
3,143 \\
2,473 \\
3,077 \\
2,842\end{array}$ & $\begin{array}{r}49 \\
84 \\
106 \\
130 \\
125 \\
90 \\
105 \\
100 \\
102\end{array}$ \\
\hline & & Total & 3,270 & 36,040 & 38,151 & 94 \\
\hline
\end{tabular}

In order to investigate the difference between civil servants and the rest of the insured population in Northern Ireland in more detail, arrangements were made to analyse the national insurance sickness records for days lost during the year ended May 31, 1959 , by age and diagnosis for men and single women. The expected number of days of sickness taken by civil servants, men and women separately, was calculated from the insurance data for each age group separately, the "all ages" figure being an age-standardized ratio; Table II (opposite) shows the percentage ratio of the observed to the expected number of days absent (hereinafter called the "absence ratio") for some of the main diagnostic groups of the International Statistical Classification of Diseases (50 list).

The age-standardized absence ratio for all diagnoses was about 50 per cent. for both men and single women, but there were appreciable differences between the diagnostic groups. For men the absence ratio for the common cold was over 200 for all ages except 20 to 29: for tonsillitis the absence ratio was over 100 except for ages 15 to 19 , and was over 400 for ages 40 to 44 , and over 900 for ages 55 to 59; for all other respiratory diseases the absence ratio was well below 100 up to age 24, was nearer 200 for ages 25 to 44 , and fell below 100 for ages 45 to 54 , rising to 103 for the age group 55 to 59 ; for diarrhoea and enteritis the absence ratio was below 100 up to age 29 , but it was more than 100 for all other age groups, being especially higher (509) for the 35 to 39 age group. The age-standardized absence ratio for men was less than $\mathbf{5 0}$ for tuberculosis, psychoneurosis, heart disease, diseases of the veins, bronchitis, arthritis, and rheumatism.

For single women the absence ratio for the common cold was only less than 200 for three age groups ( 20 to 24,35 to 39 , and 40 to 44 ), and it was particularly high after age 45 ; for tonsillitis the absence ratio was 60 for ages 15 to 19 , and 64 for ages 55 to 59 , but it was over 100 for all other ages, being particularly high (419) in the 40 to 44 age group as in the case of men; for diarrhoea and enteritis the absence ratio was less than 100 for ages 40 to 44 and 55 to 59 , was 159 for ages 35 to 39 , and over 200 for all other age groups, being as high as 616 for the ages 30 to 34 and 760 for ages 50 to 54; for other diseases of the digestive system the absence ratio was particularly high for ages 35 to 44 . The age-standardized absence ratio for single women was less than $\mathbf{5 0}$ for tuberculosis, psychoneurosis, heart disease, hypertensive disease, diseases of the veins, arthritis, and rheumatism, and other diseases of the bones.

The diagnoses in which the civil service figures were greatly in excess were normally those leading to short durations of absence, such as the common cold and tonsillitis, and this probably accounts for the apparent paradox of civil servants having more spells off work but fewer days lost per head per annum. 
TABLE II

COMPARISON OF ACTUAL EXPERIENCE OF CIVIL SERVANTS DURING 1958 FOR CERTAIN DIAGNOSES WITH THAT EXPECTED ACCORDING TO DATA FOR THE REST OF THE INSURED POPULATION OF NORTHERN IRELAND

\begin{tabular}{|c|c|c|c|c|c|c|c|c|c|c|c|c|c|}
\hline \multirow{2}{*}{$\begin{array}{c}\text { I.S.C. } \\
\text { No. }\end{array}$} & \multirow[t]{2}{*}{ Diagnosis } & \multirow[t]{2}{*}{ Sex } & \multirow{2}{*}{$\begin{array}{c}\text { Actual } \\
\text { Total } \\
\text { Days of } \\
\text { Sickness }\end{array}$} & \multicolumn{9}{|c|}{$\begin{array}{l}\text { Absence Ratios* } \\
\text { Age Groups (yrs) }\end{array}$} & \multirow{2}{*}{$\begin{array}{c}\text { Age- } \\
\text { Standardized } \\
\text { Absence } \\
\text { Ratio }\end{array}$} \\
\hline & & & & $15-19$ & $20-24$ & $25-29$ & $30-34$ & $35-39$ & $40-44$ & $45-49$ & $50-54$ & $55-59$ & \\
\hline 1 & Tuberculosis & $\begin{array}{l}\text { Males } \ldots . . \\
\text { Single Women }\end{array}$ & $\begin{array}{r}1,867 \\
586\end{array}$ & 二 & $\begin{array}{l}52 \\
29\end{array}$ & 二 & $\begin{array}{l}62 \\
61\end{array}$ & 198 & 二 & = & 二 & 二 & $\begin{array}{l}47 \\
12\end{array}$ \\
\hline 19 & Psychoneurosis & $\begin{array}{l}\text { Males _... } \\
\text { Single Women }\end{array}$ & $\begin{array}{l}1,772 \\
2,561\end{array}$ & $\overline{16}$ & $\begin{array}{r}103 \\
42\end{array}$ & $\begin{array}{l}13 \\
47\end{array}$ & $\begin{array}{r}36 \\
9\end{array}$ & $\begin{array}{l}32 \\
38\end{array}$ & $\begin{array}{l}53 \\
10\end{array}$ & $\begin{array}{l}33 \\
10\end{array}$ & 33 & $\begin{array}{l}12 \\
16\end{array}$ & $\begin{array}{l}32 \\
26\end{array}$ \\
\hline 25 & Heart disease & $\begin{array}{l}\text { Males } \ldots \\
\text { Single Women }\end{array}$ & $\begin{array}{r}1,407 \\
87\end{array}$ & 二 & 二 & $\overline{22}$ & $=$ & -9 & $\begin{array}{r}5 \\
17\end{array}$ & 83 & $\begin{array}{r}69 \\
1\end{array}$ & 31 & $\begin{array}{r}45 \\
4\end{array}$ \\
\hline 26 & Hypertensive disease & $\begin{array}{l}\text { Males } \ldots . . \\
\text { Single Women }\end{array}$ & $\begin{array}{l}608 \\
170\end{array}$ & 二 & $\overline{-}$ & 二 & 二 & $\frac{24}{-}$ & $\frac{36}{-}$ & $\overline{-}$ & $\begin{array}{r}67 \\
6\end{array}$ & $\begin{array}{l}50 \\
17\end{array}$ & $\begin{array}{r}50 \\
8\end{array}$ \\
\hline 27 & Diseases of the veins & $\begin{array}{l}\text { Males } \ldots . . \\
\text { Single Women }\end{array}$ & $\begin{array}{l}395 \\
270\end{array}$ & 二 & $1 \overline{100}$ & $\overline{26}$ & $\begin{array}{r}153 \\
48\end{array}$ & $\begin{array}{r}52 \\
1\end{array}$ & $\begin{array}{l}15 \\
29\end{array}$ & $\overline{43}$ & $\begin{array}{l}38 \\
31\end{array}$ & 89 & $\begin{array}{l}48 \\
22\end{array}$ \\
\hline 28 & Common cold & $\begin{array}{l}\text { Males } \ldots \ldots \\
\text { Single Women }\end{array}$ & $\begin{array}{r}712 \\
1,143\end{array}$ & $\begin{array}{l}250 \\
225\end{array}$ & $\begin{array}{l}193 \\
188\end{array}$ & $\begin{array}{r}58 \\
272\end{array}$ & $\begin{array}{l}248 \\
423\end{array}$ & $\begin{array}{l}295 \\
193\end{array}$ & $\begin{array}{l}322 \\
193\end{array}$ & $\begin{array}{l}523 \\
383\end{array}$ & $\begin{array}{l}341 \\
969\end{array}$ & $\begin{array}{l}429 \\
488\end{array}$ & $\begin{array}{l}316 \\
265\end{array}$ \\
\hline 29 & Tonsillitis $\quad \ldots$ & $\begin{array}{l}\text { Males } \ldots . . \\
\text { Single Women }\end{array}$ & $\begin{array}{l}1,294 \\
1,631\end{array}$ & $\begin{array}{l}90 \\
60\end{array}$ & $\begin{array}{l}110 \\
134\end{array}$ & $\begin{array}{l}142 \\
128\end{array}$ & $\begin{array}{l}337 \\
168\end{array}$ & $\begin{array}{l}115 \\
152\end{array}$ & $\begin{array}{l}418 \\
419\end{array}$ & $\begin{array}{l}150 \\
162\end{array}$ & $\begin{array}{l}197 \\
261\end{array}$ & $\begin{array}{r}932 \\
64\end{array}$ & $\begin{array}{l}216 \\
129\end{array}$ \\
\hline 30 & Influenza $\quad \ldots$ & $\begin{array}{l}\text { Males } \\
\text { Single Women }\end{array}$ & $\begin{array}{l}3,184 \\
4,057\end{array}$ & $\begin{array}{l}63 \\
44\end{array}$ & $\begin{array}{r}111 \\
95\end{array}$ & $\begin{array}{r}56 \\
112\end{array}$ & $\begin{array}{r}96 \\
136\end{array}$ & $\begin{array}{r}55 \\
125\end{array}$ & $\begin{array}{r}67 \\
100\end{array}$ & $\begin{array}{r}100 \\
77\end{array}$ & $\begin{array}{r}86 \\
162\end{array}$ & $\begin{array}{l}106 \\
232\end{array}$ & $\begin{array}{r}80 \\
105\end{array}$ \\
\hline 32 & Bronchitis $\ldots$ & $\begin{array}{l}\text { Males } \\
\text { Single Women }\end{array}$ & $\begin{array}{l}2,293 \\
2,517\end{array}$ & $\begin{array}{r}8 \\
56\end{array}$ & $\begin{array}{r}32 \\
136\end{array}$ & $\begin{array}{r}24 \\
120\end{array}$ & $\begin{array}{r}107 \\
38\end{array}$ & $\begin{array}{r}67 \\
105\end{array}$ & $\begin{array}{l}41 \\
50\end{array}$ & $\begin{array}{l}53 \\
29\end{array}$ & $\begin{array}{l}57 \\
80\end{array}$ & $\begin{array}{l}32 \\
91\end{array}$ & $\begin{array}{l}46 \\
76\end{array}$ \\
\hline 34 & $\begin{array}{c}\text { All other respiratory } \\
\text { diseases } \ldots\end{array}$ & $\begin{array}{l}\text { Males } \\
\text { Single Women }\end{array}$ & $\begin{array}{l}1,208 \\
1,201\end{array}$ & $\begin{array}{l}21 \\
90\end{array}$ & $\begin{array}{l}14 \\
86\end{array}$ & $\begin{array}{l}174 \\
120\end{array}$ & $\begin{array}{l}117 \\
100\end{array}$ & $\begin{array}{l}176 \\
125\end{array}$ & $\begin{array}{r}165 \\
67\end{array}$ & $\begin{array}{l}80 \\
39\end{array}$ & $\begin{array}{r}30 \\
500\end{array}$ & $\begin{array}{l}103 \\
175\end{array}$ & $\begin{array}{l}111 \\
104\end{array}$ \\
\hline 35 & $\begin{array}{c}\text { Diseases of the } \\
\text { stomach } \ldots\end{array}$ & $\begin{array}{l}\text { Males } \ldots . . \\
\text { Single Women }\end{array}$ & $\begin{array}{r}2,027 \\
909\end{array}$ & $\begin{array}{r}50 \\
32 \\
\end{array}$ & $\begin{array}{l}33 \\
71\end{array}$ & $\begin{array}{r}14 \\
122\end{array}$ & $\begin{array}{l}28 \\
32\end{array}$ & $\begin{array}{l}69 \\
27\end{array}$ & $\begin{array}{l}78 \\
66\end{array}$ & $\begin{array}{l}63 \\
29\end{array}$ & $\begin{array}{l}42 \\
20\end{array}$ & $\begin{array}{l}30 \\
66\end{array}$ & $\begin{array}{l}52 \\
50\end{array}$ \\
\hline 38 & $\begin{array}{c}\text { Diarrhoea and } \\
\text { enteritis } \ldots\end{array}$ & $\begin{array}{l}\text { Males } \\
\text { Single Women }\end{array}$ & $\begin{array}{l}535 \\
711\end{array}$ & $2 \overline{00}$ & $\begin{array}{r}50 \\
280\end{array}$ & $\begin{array}{r}29 \\
316\end{array}$ & $\begin{array}{l}107 \\
616\end{array}$ & $\begin{array}{l}509 \\
159\end{array}$ & $\begin{array}{r}158 \\
63\end{array}$ & $\begin{array}{r}100 \\
217\end{array}$ & $\begin{array}{l}156 \\
760\end{array}$ & $\begin{array}{r}191 \\
73\end{array}$ & $\begin{array}{l}204 \\
229\end{array}$ \\
\hline 40 & $\begin{array}{l}\text { Other diseases of the } \\
\text { digestive system } \ldots\end{array}$ & $\begin{array}{l}\text { Males } \ldots . . \\
\text { Single Women }\end{array}$ & $\begin{array}{l}616 \\
574\end{array}$ & $\begin{array}{r}900 \\
46\end{array}$ & $\begin{array}{r}71 \\
148\end{array}$ & $\begin{array}{l}39 \\
95\end{array}$ & $\begin{array}{r}91 \\
158\end{array}$ & $\begin{array}{r}132 \\
1,611\end{array}$ & $\begin{array}{r}61 \\
837\end{array}$ & $\begin{array}{l}50 \\
45\end{array}$ & $\begin{array}{l}566 \\
142\end{array}$ & $\begin{array}{r}113 \\
18\end{array}$ & $\begin{array}{l}149 \\
149\end{array}$ \\
\hline 46 & $\begin{array}{c}\text { Arthritis and } \\
\text { rheumatism }\end{array}$ & $\begin{array}{l}\text { Males } \ldots . . \\
\text { Single Women }\end{array}$ & $\begin{array}{l}1,537 \\
1,533\end{array}$ & $\overline{20}$ & $\overline{52}$ & $\begin{array}{r}11 \\
106\end{array}$ & $\begin{array}{l}38 \\
65\end{array}$ & $\begin{array}{l}61 \\
65\end{array}$ & $\begin{array}{l}24 \\
73\end{array}$ & $\begin{array}{l}36 \\
29\end{array}$ & $\begin{array}{r}24 \\
9\end{array}$ & $\begin{array}{r}16 \\
5\end{array}$ & $\begin{array}{l}28 \\
30\end{array}$ \\
\hline 47 & Disease of the bones & $\begin{array}{c}\text { Males } \ldots \ldots \\
\text { Single Women }\end{array}$ & $\begin{array}{l}734 \\
219\end{array}$ & $\overline{18}$ & $\begin{array}{l}113 \\
112 \\
\end{array}$ & $\begin{array}{l}55 \\
14\end{array}$ & $\begin{array}{r}141 \\
5\end{array}$ & 21 & $\begin{array}{r}46 \\
7\end{array}$ & 139 & $\begin{array}{l}49 \\
49\end{array}$ & 34 & $\begin{array}{l}58 \\
21\end{array}$ \\
\hline \multicolumn{2}{|c|}{ All Diagnoses } & $\begin{array}{l}\text { Males } \\
\text { Single Women }\end{array}$ & $\begin{array}{l}30,115 \\
28,679\end{array}$ & $\begin{array}{l}23 \\
46\end{array}$ & $\begin{array}{l}55 \\
71\end{array}$ & $\begin{array}{l}39 \\
75\end{array}$ & $\begin{array}{l}62 \\
60\end{array}$ & $\begin{array}{l}79 \\
46\end{array}$ & $\begin{array}{l}53 \\
43\end{array}$ & $\begin{array}{l}52 \\
33\end{array}$ & $\begin{array}{l}49 \\
32\end{array}$ & $\begin{array}{l}35 \\
36\end{array}$ & $\begin{array}{l}51 \\
46\end{array}$ \\
\hline
\end{tabular}

*Figures represent the ratio of actual days of sickness in the year to the expected number in percentage form

Even within the civil service there were wide variations between grades, and Table III (overleaf) shows the ratio between the actual and expected days of sickness for a selected number of diagnoses and three grades for men. (All those in the grade Junior Staff Officer and above would be earning $£ 1,000$ per annum or more). The expected number of days was calculated from the figures for all nonindustrial civil servants, which covers the general service grades and professional and technical staff for each age group separately, the "all ages" figure being an age-standardized ratio.
Although the number of days in some of the age and diagnostic groups was small, the general impression from Table III is that the distribution of sickness differs between grades. The higher-grade staff had relatively fewer days off work than others because of psychoneurosis, bronchitis, diseases of stomach, arthritis, and rheumatism, but had more days off because of heart disease. Messengers, on the other hand, had more days off than expected for bronchitis, arthritis, and rheumatism, and less for heart complaints than the rest of the civil service. Among clerks the age standardized ratio 
TABLE III

COMPARISON OF ACTUAL EXPERIENCE FOR MALE GRADE FOR CERTAIN DIAGNOSES WITH THE EXPECTED EXPERIENCE ACCORDING TO DATA FOR THE CIVIL SERVICE MALE NON-INDUSTRIAL STAFF DURING 1958

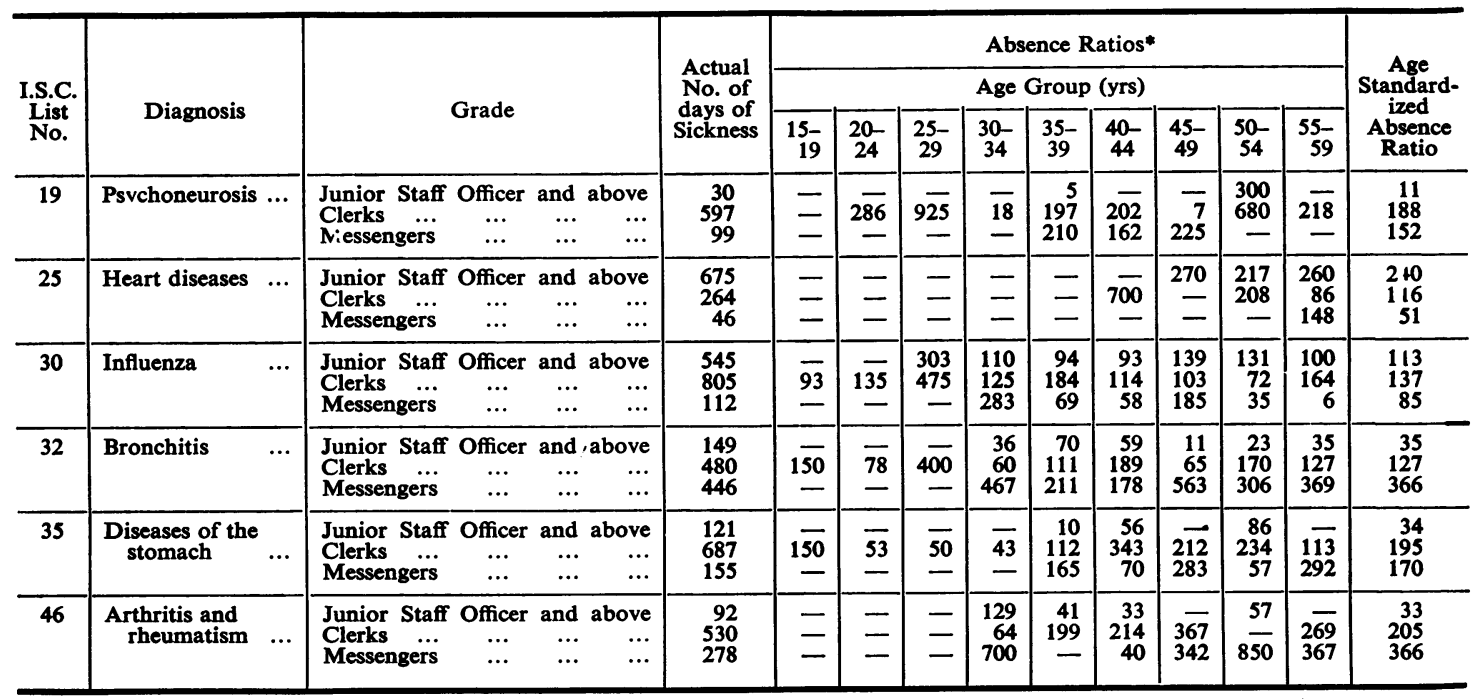

* Figures represent the ratio of actual days of sickness in the year to the expected number in percentage form.

was always greater than 100 and was around 200 for diseases of the stomach, arthritis, and rheumatism.

There are relatively few women in the higher grades of the civil service in Northern Ireland with the result that the numbers are confined to a comparatively shorter salary range than men. The opportunity has been taken in this study to compare the sickness experience of permanent with temporary female officers of a similar grade, viz. Clerical Assistant Grade I. There are roughly the same numbers in each category, about 280 , although the members of the temporary staff are relatively younger. The expected number of days for each 5-year age group was calculated from the experience of all women in the Civil Service, and as before the ratio of actual to expected days off was calculated for each age group. For ease of reference only the age-standardized ratios for each diagnosis are quoted in Table IV. Apart from tonsillitis, the ratio for the permanent staff was appreciably lower than that for the temporary staff for this grade in the main diagnostic groups quoted. The experience of one year only and the relatively small numbers in some age groups makes one hesitate to draw conclusions from these figures.
TABLE IV

COMPARISON OF ACTUAL EXPERIENCE OF PERMANENT AND TEMPORARY FEMALE CLERICAL ASSISTANTS (GRADE I) ACCORDING TO DATA FOR THE CIVII SERVICE FEMALE NON-INDUSTRIAL STAFF DURING 1958

\begin{tabular}{|c|c|c|c|c|c|c|}
\hline \multirow{3}{*}{$\begin{array}{l}\text { I.S.C. } \\
\text { List } \\
\text { No. }\end{array}$} & \multirow{3}{*}{ Diagnosis } & & \multicolumn{4}{|c|}{ Female Clerical Assistants (Grade I) } \\
\hline & & & \multicolumn{2}{|c|}{$\begin{array}{l}\text { Actual Number } \\
\text { of Days of } \\
\text { Sickness }\end{array}$} & \multicolumn{2}{|c|}{$\begin{array}{l}\text { Absence } \\
\text { Ratios* }\end{array}$} \\
\hline & & & $\begin{array}{c}\text { Perma- } \\
\text { nent }\end{array}$ & $\begin{array}{l}\text { Temp- } \\
\text { orary }\end{array}$ & $\begin{array}{c}\text { Perma- } \\
\text { nent }\end{array}$ & $\begin{array}{l}\text { Temp- } \\
\text { orary }\end{array}$ \\
\hline $\begin{array}{l}19 \\
28 \\
29 \\
30 \\
35 \\
46\end{array}$ & $\begin{array}{l}\text { Psychoneurosis } \\
\text { Common cold } \\
\text { Tonsillitis } \\
\text { Influenza . } \\
\text { Diseases of the } \\
\text { stomach } \\
\text { Arthritis and } \\
\text { rheumatism }\end{array}$ & $\begin{array}{l}\ldots \\
\ldots \\
\ldots \\
\ldots \\
\ldots\end{array}$ & $\begin{array}{l}239 \\
114 \\
338 \\
534 \\
113 \\
131\end{array}$ & $\begin{array}{l}810 \\
165 \\
243 \\
869 \\
141 \\
252\end{array}$ & $\begin{array}{r}54 \\
64 \\
150 \\
83 \\
72 \\
72 \\
52\end{array}$ & $\begin{array}{l}365 \\
145 \\
129 \\
208 \\
147 \\
196\end{array}$ \\
\hline
\end{tabular}

- Figures represent the age-standardized ratio of actual days of sickness in the year as a percentage of the expected number.

\section{SuMmary}

(1) The sickness experience of civil servants in Northern Ireland during 1958 has been examined in some detail and compared with data derived from National Insurance records and London Transport Executive statistics. 
(2) The results confirm the impression gained from a previous study that, for all causes of absence combined, civil servants have relatively fewer days off work because of sickness than the rest of the insured population in the Province, but that for some of the short-term illnesses they actually have more days off than would be expected from the insurance data.

(3) The age-standardized ratio suggests that the civil service experience is not appreciably different from that of the clerical staff of the London Transport Executive, and it is possible that other office staffs in Northern Ireland have a sickness experience more akin to that of the civil service than to that of industrial workers.

(4) Within the civil service the sickness experience of men in the higher grades is different from that of clerks; messengers differ from administrative and clerical staff and have relatively more days off work through bronchitis, arthritis, and rheumatism than the rest of the civil service.
We are indebted to Dr. E. A. Cheeseman, Department of Social and Preventive Medicine, Queen's University of Belfast, for his advice and help, and to the Director of Establishments, Ministry of Finance, for permission to publish this paper.

\section{REFERENCES}

Barr, A. (1960). Brit. J. prev. soc. Med., 12, 61.

Chiesman. W. E. (1957).Roy. Soc. Hlth., J. 77, 681

Jones, C. M. (1959). Ibid., 13, 74.

Kidd, C. W., and Park, A. T. (1959). Med. Offr, 101, 327.

_- (1960a). Ann. rheum. Dis., 19, 158.

- (1960b). Med. Offr, 103, 339.

London Transport Executive (1956). "Health in Industry". Butterworth, London.

Morris, J. N. (1957). "Uses of Epidemiology". Livingston, Edinburgh.

Moss, B. J. L. (1959). Med. Offr, 102, 293.

Park, A. T., and Kidd, C. W. (1958). Brit. J. prer. soc. Med., 12, 75.

Reid, D. D. (1957). Roy. Soc. Hlth J., 77, 675.

Spratling, F. H. (1957). Ibid., 77, 667.

Warren, M. D. (1960). Med. Offr, 104, 205. 